\title{
Air Quality Impact of Biomass Co-Firing with Coal at a Power Plant in the Greater Houston Area
}

\author{
Iqbal Hossan', Venkata Sai Vamsi Botlaguduru¹, Hongbo Du1, Raghava Rao Kommalapati1,2*, \\ Ziaul Huque ${ }^{1,3}$
}

${ }^{1}$ Center for Energy \& Environmental Sustainability, Prairie View A \& M University, Prairie View, TX, USA

${ }^{2}$ Dept. of Civil \& Environmental Engineering, Prairie View A \& M University, Prairie View, TX, USA

${ }^{3}$ Dept. of Mechanical Engineering, Prairie View A \& M University, Prairie View, TX, USA

Email: *rrkommalapati@pvamu.edu

How to cite this paper: Hossan, I., Botlaguduru, V.S.V., Du, H.B., Kommalapati, R.R. and Huque, Z. (2018) Air Quality Impact of Biomass Co-Firing with Coal at a Power Plant in the Greater Houston Area. Open Journal of Air Pollution, 7, 263-285. https://doi.org/10.4236/ojap.2018.73013

Received: August 22, 2018

Accepted: September 10, 2018

Published: September 13, 2018

Copyright (๑) 2018 by authors and Scientific Research Publishing Inc. This work is licensed under the Creative Commons Attribution International License (CC BY 4.0).

http://creativecommons.org/licenses/by/4.0/

\begin{abstract}
The Houston-Galveston-Brazoria (HGB) area of Texas is a moderate nonattainment region for ozone, and has a history of severe summer ozone episodes. W. A. Parish power plant (WAP) located in the greater Houston area is the largest coal and natural gas based electricity generating unit (EGU) in Texas. Forest residue is an abundant renewable resource, and can be used to offset coal usage at EGUs. This study evaluates the impact of co-firing 5\%, $10 \%$, and $15 \%$ (energy-basis) of forest residue at WAP on the air quality of the HGB area. Photochemical modeling with Comprehensive Air Quality Model with Extensions (CAMx) was conducted to investigate the air quality at three air quality monitoring sites (C696, C53, C556) in the HGB area, under two source scenarios (all-sources, point + biogenic sources). Significant reduction of $\mathrm{SO}_{2}$ and $\mathrm{O}_{3}$ was observed for $10 \%$ and $15 \%$ co-firing ratios at monitoring station (C696) close to WAP. The maximum reduction of ozone observed for $15 \%$ co-firing is $4.7 \%$ and $6.3 \%$ for all-sources and point + biogenic sources scenarios respectively. The reduction in other criteria air pollutants is not significant at all locations. The overall results from this study indicate that biomass co-firing at WAP would not lead to a significant reduction in ozone concentrations in the region during periods of peak ozone.
\end{abstract}

\section{Keywords}

Ozone, Houston, Photochemical Modeling, Biomass, Co-Firing

\section{Introduction}

The Houston-Galveston-Brazoria (HGB) region of Texas experienced high sum- 
mer ozone episodes with formation rates rising as high as $200 \mathrm{ppbh}^{-1}$ in 2001, in contrast to ozone production rates around $40 \mathrm{ppbh}^{-1}$ in other cities of the US [1] [2]. The HGB area consists of eight counties: Galveston, Brazoria, Fort Bend, Chambers, Harris, Liberty, Montgomery and Waller, and is one of the 16 air quality regions administered by the Texas Commission on Environmental Quality (TCEQ) [3]. The HGB area was designated a moderate non-attainment area and was required to attain the 8-hour $\mathrm{O}_{3}$ standard of 75 ppb which was set in 2008 [4]. A more stringent National Ambient Air Quality Standard (NAAQS) was mandated in 2015 and the eight-hour standard decreased to $70 \mathrm{ppb}$ [4]. Ground level ozone formation depends on the complex reactions of volatile organic compounds (VOCs) and $\mathrm{NO}_{\mathrm{X}}$ in the presence of solar radiation. The photochemical reactions that lead to the formation of ozone occur predominantly during hot, sunny summer days with high humidity levels [5] [6]. In this region, the formation of peroxy radicals $\left(\cdot \mathrm{RO}_{2}\right)$ which convert nitrogen monoxide (NO) back to nitrogen dioxide $\left(\mathrm{NO}_{2}\right)$ and reproduce hydroxyl radical $(\cdot \mathrm{OH})$, sustains high net $\mathrm{O}_{3}$ formation [7] [8]. Ground level ozone is largely a result of precursor emissions from anthropogenic sources such as petrochemical plants, fossil-fuel based electricity generating units (EGU), and mobile sources [9]. Power generation from fossil fuel emits a significant amount of $\mathrm{NO}_{\mathrm{X}}$, and emissions from EGUs can have a substantial impact on downwind air quality [10]. EGUs are the leading point source emitters of $\mathrm{NO}_{\mathrm{x}}$ and $\mathrm{SO}_{2}$ which are linked with the formation of photochemical ozone and acid deposition [11] [12] [13]. W. A. Parish (WAP) power plant is one of the largest coal-based power plants in the U.S. and is located in Fort Bend County of the HGB area. Rapid $\mathrm{O}_{3}$ formation occurs when the anthropogenic VOC emissions from the Houston Ship Channel region combine with $\mathrm{NO}_{\mathrm{x}}$ emissions from EGUs and mobile sources in the HGB area [9] [14]. WAP has eight units with a capacity of $3653 \mathrm{MW}$, with Units 1 - 4 fueled by natural gas and generating 1191 MW; Units 5 - 8 use coal and generate 2470 MW electricity. The concentration of aerosols and gas phase species from WAP is significantly higher compared to petrochemical industries in the region [15]. The Texas Air Quality Study II, on $19^{\text {th }}$ September, 2006 tracked the plume from WAP and estimated the ozone production efficiency (OPE) as 4.4 at the plume age of $0.6 \mathrm{~h}$, indicating that conditions are suitable for rapid $\mathrm{O}_{3}$ formation when emissions from WAP combine with VOC emissions from the ship channel region [14].

An effective way to reduce emissions of criteria air pollutants from EGUs is to supplement coal usage with renewable energy sources such as, biomass, wind and solar [16] [17] [18] [19]. One of the renewable energy resources that are available locally in Texas, for power generation is forest residue [20]. Logging residue, the unused portions of harvested trees left in the woods, is potentially available for co-firing and includes tops, limbs, and un-utilized cull trees. Stumps are not feasible for co-firing, due to the cost of obtaining stump biomass being prohibitively high [20]. Currently, logging residues are either burned or 
left in open fields by forestland owners as markets for logging residues are non-existent [21]. Biomass can be converted into electricity by direct combustion, co-firing with coal, gasification, and pyrolysis. Substituting biomass for a portion of coal in an existing coal power plant, termed co-firing has economic and environmental advantages [17]. Biomass can be co-fired at 10\%-25\% (mass basis) without significant impacts to heat release characteristics of boilers [22] [23]. Co-firing is an economically feasible option for introducing new biomass power generation in most existing power plants. Coal can be replaced up to $15 \%$ by biomass in an existing power plant with minor modifications, and this replacement ratio is found to be optimum for cost-effectiveness [24]. Local availability of sufficient quantity of low-cost biomass is the leading factor for economic advantages of electricity production. U.S. electricity from biomass has increased by around $18 \%$ in ten years from 2005 to 2015 , and $1.6 \%$ of the total electricity is from biomass as of 2015 [25]. A recent study by Kommalapati et al., (2018) reported the changes in life cycle environmental impacts, across 15 mid-point impact categories, due to co-firing of forest residue with coal in the HGB area [19]. This life cycle assessment (LCA) study estimates that co-firing of biomass at the WAP plant would reduce life cycle $\mathrm{NO}_{\mathrm{x}}$ and VOC emissions by $11.6 \%$ and $7.7 \%$, for a co-firing ratio of $15 \%$ (energy basis) [19]. The current study builds on the estimates for combustion stage emissions, provided by Kommalapati et al., (2018), and evaluates the impact on regional air quality of the HGB area, due to biomass co-firing at WAP plant. Photochemical modeling was conducted with the Comprehensive Air Quality Model with Extensions $(\mathrm{CAMx})$, and results were visualized with Visualization Environment for Rich Data Interpretation (VERDI) tool. CAMx is a Eulerian photochemical dispersion model that simulates the emissions, dispersion, chemical reaction, and removal of pollutants by marching the Eulerian continuity equation forward in time for each chemical species on a system of nested three-dimensional grids [26]. The objective of the current study is to evaluate the impact of biomass co-firing at WAP power plant at the ratios of 5\%,10\% and 15\% (energy-basis), on the air quality of the HGB region during the June 2012 ozone episode.

\section{Methodology}

\subsection{Emissions}

Base-case emissions for combustion stage at the WAP plant, were obtained from TCEQ's Airs Facility Subsystem (AFS) files for modeling 2012 ozone episode. The average emissions for the four coal units of WAP plant, during June 2012 are described in Table 1 , as emission rate in tonnes/hr $(\mathrm{t} / \mathrm{hr})$. Estimates for emissions reduction at the combustion stage were obtained from Kommalapati et al., (2018), and are summarized in Table 2 [19] [27]. Biomass co-firing is considered only in the coal units of WAP, which were Units 5 - 8, and were controlled by Selective Catalytic Reduction for $\mathrm{NO}_{\mathrm{X}}$. 
Table 1. Average base-case emissions of air pollutants from combustion stage of coal units.

\begin{tabular}{cccccc}
\hline Pollutant & Measure & $\begin{array}{c}\text { Unit-5 } \\
(650 \mathrm{MW})\end{array}$ & $\begin{array}{c}\text { Unit-6 } \\
(650 \mathrm{MW})\end{array}$ & $\begin{array}{c}\text { Unit-7 } \\
(560 \mathrm{MW})\end{array}$ & $\begin{array}{c}\text { Unit-8 } \\
(610 \mathrm{MW})\end{array}$ \\
\hline $\mathrm{NO}_{\mathrm{x}}$ & $(\mathrm{t} / \mathrm{hr})$ & 0.1818 & 0.1631 & 0.0982 & 0.1356 \\
$\mathrm{VOC}$ & $(\mathrm{kg} / \mathrm{MWh})$ & 0.2797 & 0.2508 & 0.1753 & 0.2224 \\
$\mathrm{CO}$ & $(\mathrm{t} / \mathrm{hr})$ & 0.0037 & 0.0044 & 0.0042 & 0.0049 \\
$\mathrm{PM}_{2.5}$ & $(\mathrm{~kg} / \mathrm{MWh})$ & 0.0057 & 0.0068 & 0.0075 & 0.0081 \\
$\mathrm{SO}_{2}$ & $(\mathrm{t} / \mathrm{hr})$ & 0.1256 & 0.0714 & 0.1401 & 0.2910 \\
\hline
\end{tabular}

Table 2. Percentage reduction in combustion stage emissions due to co-firing [19].

\begin{tabular}{cccccc}
\hline Co-firing ratio & $\mathrm{NO}_{\mathrm{X}}$ & $\mathrm{VOC}$ & $\mathrm{CO}$ & $\mathrm{PM}_{2.5}$ & $\mathrm{SO}_{2}$ \\
\hline $5 \%$ & $5.23 \%$ & $2.80 \%$ & $0.57 \%$ & $2.94 \%$ & $3.84 \%$ \\
$10 \%$ & $10.3 \%$ & $5.60 \%$ & $3.44 \%$ & $7.44 \%$ & $6.89 \%$ \\
$15 \%$ & $15.1 \%$ & $8.40 \%$ & $6.31 \%$ & $11.9 \%$ & $9.94 \%$
\end{tabular}

\subsection{Emissions Processing}

Emission Processing System 3 (EPS3) consists of a series of FORTRAN modules that perform intensive data manipulations, producing an emissions inventory for photochemical modeling [26]. EPS3 was used to process the Airs Facility Subsystem (AFS) files publically available at the Texas Commission on Environmental Quality website [28]. This study used PREPNT, SPCEMS, TMPRL, PSTPNT, PIGEMS, GRDEM, MRGUAM modules to process data. The output from LCA study for combustion stage was used to modify only point sources file related to EGUs in the HGB area. All other emission files (Biogenic, area, nonroad, offroad, oil and gas, onroad, and emissions from Mexico and Canada) are retained intact and used in final module (PIGEMS and MRGUAM) of EPS3 for merging.

\subsection{Model and Site Selection}

CAMx version 6.31 with improved halogen chemistry was used to predict air pollutant concentration in the HGB area. CAMx uses the $36 \mathrm{~km}$ master grid as coarsest grid and then moves to the finer grids of $12 \mathrm{~km}$ and $4 \mathrm{~km}$. Lambert Conformal Conic map projection is used in Texas ozone modeling domains, where first true latitude, second true latitude, and central longitude are $33^{\circ} \mathrm{N}$, $45^{\circ} \mathrm{N}$ and $97^{\circ} \mathrm{W}$ respectively. The modeling domain for this study includes emission sources in Canada, the U.S., and Mexico. The coarse domain covers the area under Easting $(-2735,2592)$ and Northing $(-2088,1944)$ coordinate, also the grid areas are divided into $148 \times 112$ cells. The tx_12 km domain has $149 \times 110$ numbers of cells and the tx_4 $\mathrm{km}$ domain is divided into $191 \times 218$ cells. The five major data classes needed as input for CAMx modeling are emissions, meteorology, photolysis, geographic, air quality. In this study, four simulations 
were completed for each day, including a base case (no co-firing), a 5\% co-firing case, a $10 \%$ co-firing case, and a 15\% co-firing case. Each case has two scenarios: all-sources (biogenic, point, area, mobile), and point + biogenic sources. In all the cases, boundary condition, top concentration, meteorology, land use, photolysis are obtained from TCEQs Texas Air Quality Modeling Files and Information (2012 Episodes), except low-level emission and elevated-level emission files [29]. The CAMx output is in binary format, and VERDI software is used to visualize these results. Air quality impact analysis is considered at three air monitoring stations to compare the effect of co-firing. The details of the three selected sites are provided in Table 3 and Figure 1. University of Houston, Sugarland (C696) monitoring location, is selected as it is the closest monitoring station $(11.02 \mathrm{~km})$ to the WAP plant. Houston Bayland Park (C53) located at Harris County, and La Porte Sylvan Beach (C556); were selected due to high population density at Bayland Park and proximity to Houston Ship Channel for C556 respectively.

\section{Results and Discussion}

\subsection{Nitrogen Oxides $\left(\mathrm{NO}_{\mathrm{x}}\right)$}

The maximum concentration of $\mathrm{NO}_{\mathrm{x}}$ in June 2012 was observed at 7:00 hr on $21^{\text {st }}$ June, and $11^{\text {th }}$ June for both base and point + biogenic cases respectively. Co-firing of biomass does not affect $\mathrm{NO}_{\mathrm{x}}$ concentration during the highest concentration hours. There are some reductions observed due to co-firing, which occur when the concentration is less than $7 \mathrm{ppb}$ for the base case, as presented in Figure 2. There is no change of $\mathrm{NO}_{\mathrm{x}}$ level for the $5 \%$ co-firing case, except at 14:00 hr on June $3^{\text {rd }}$, where $1 \mathrm{ppb}$ reduction was observed from a 3 ppb base-case concentration. On June $18^{\text {th }}(8: 00 \mathrm{hr})$, the concentration reduced to $12 \mathrm{ppb}$ from $13 \mathrm{ppb}$ for the $15 \%$ co-firing case. The possible reasons for the insignificant effect due to biomass co-firing could be that WAP power plant is controlled for $\mathrm{NO}_{\mathrm{X}}$ emissions by using selective catalytic reduction (SCR), and $90 \%$ emissions reduction was already observed from 1997 to 2010 [9]. In addition, 67\% of $\mathrm{NO}_{\mathrm{x}}$ in the HGB area came from mobile sources in 2014, and even in point source emissions, non-EGUs emitted an almost double amount of $\mathrm{NO}_{\mathrm{x}}$ than EGUs in 2012 [30]. So, considering all-sources for CAMx modeling may have a lower effect on ambient concentrations at the monitoring stations (C696). In addition, meteorological conditions like wind speed and wind direction may dampen the effect of reduced stack emissions on changes in ambient concentrations [31].

Table 3. Selected Monitoring Sites.

\begin{tabular}{|c|c|c|c|}
\hline Site & Location & Latitude & Longitude \\
\hline Site 1 & University of Houston Sugarland (C696) & $29^{\circ} 34^{\prime} 27^{\prime \prime} \mathrm{N}$ & $95^{\circ} 38^{\prime} 59^{\prime \prime} \mathrm{W}$ \\
\hline Site 2 & Houston Bayland Park (C53) & $29^{\circ} 41^{\prime} 45^{\prime \prime} \mathrm{N}$ & $95^{\circ} 29^{\prime} 57^{\prime \prime} \mathrm{W}$ \\
\hline Site 3 & La Porte Sylvan Beach (C556) & $29^{\circ} 39^{\prime} 19^{\prime \prime} \mathrm{N}$ & $95^{\circ} 00^{\prime} 35^{\prime \prime} \mathrm{W}$ \\
\hline
\end{tabular}




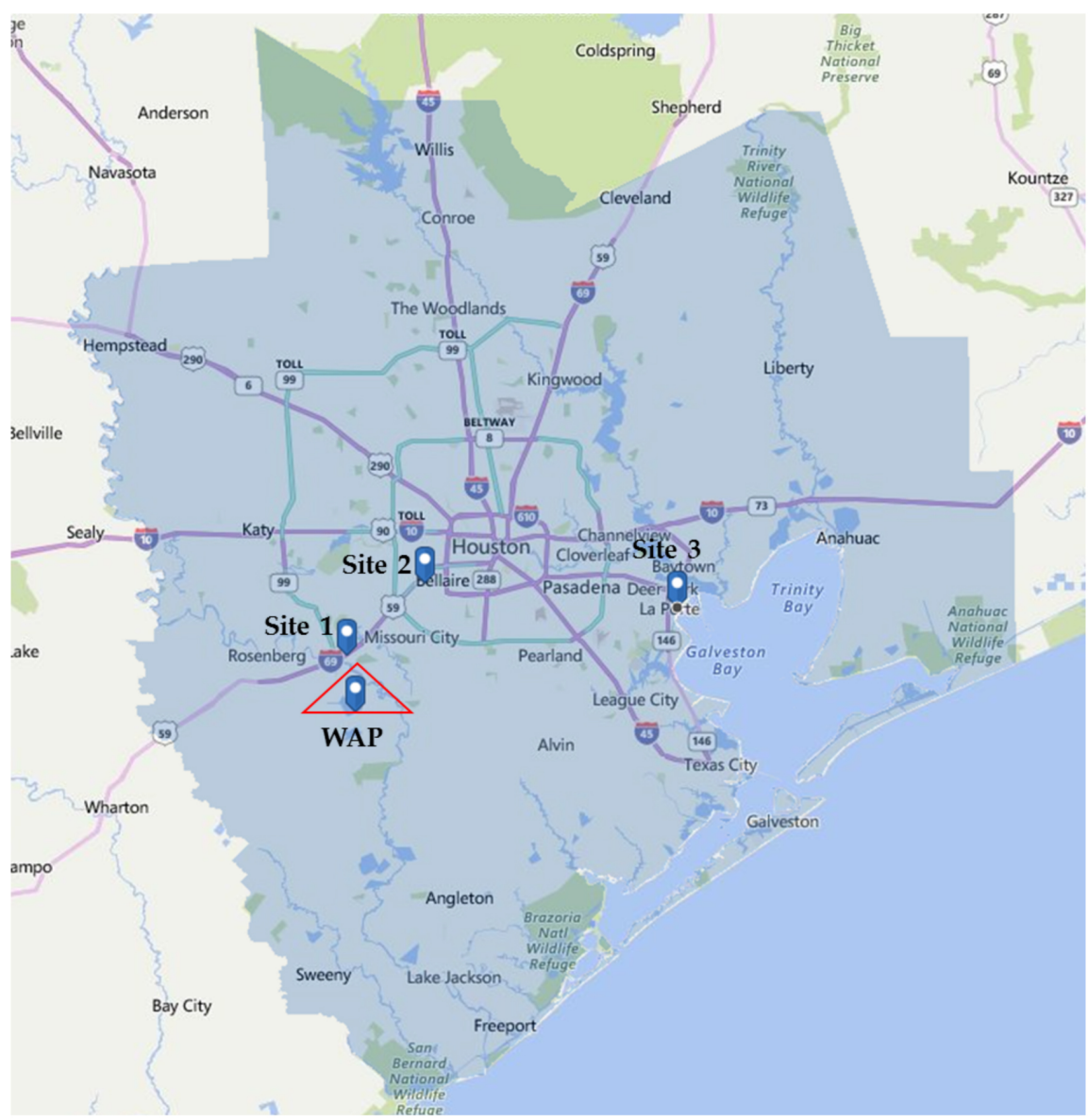

Figure 1. Location of air monitoring sites and WAP plant within the HGB area.

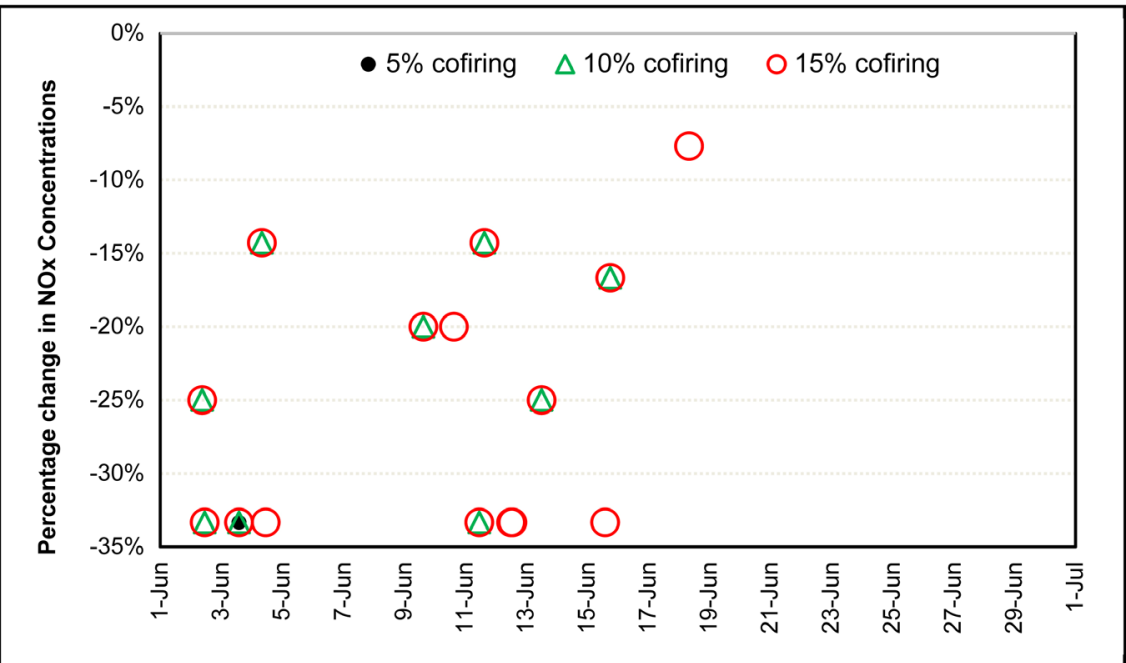

Figure 2. Reduction in $\mathrm{NO}_{\mathrm{x}}$ concentrations at C696 station due to co-firing (all-sources).

There is no significant decrease in $\mathrm{NO}_{\mathrm{x}}$ concentration due to co-firing, at the Houston Bayland Park monitoring station (C53). Only two and four hours out of the 720 hours for June 2012 showed a $1 \mathrm{ppb}$ reduction for the all-sources and point + biogenic case scenarios respectively. Both of these reductions were dur- 
ing low-concentration hours, reduction only observed for $10 \%$, and $15 \%$ co-firing case. Onroad emissions of $\mathrm{NO}_{\mathrm{x}}$ were 107.12 tons per day (tpd) in Harris County in 2012 which is 3 times more than EGUs emission of $\mathrm{NO}_{\mathrm{x}}$ in the HGB area [3]. That means that C53 is dominated by mobile source emissions. Due to downwind wind pattern from the Gulf of Mexico, the $\mathrm{NO}_{\mathrm{x}}$ emissions from a high stack of WAP can be transported to C53 location and influence the air quality depending on meteorological conditions of the day. Co-firing of biomass in WAP power plant does not have an effect on C556 station when all source considered. For point + biogenic sources, only three different hours shows reduction: The maximum reduction observed at 10:00 $\mathrm{hr}\left(6^{\text {th }} \mathrm{June}\right)$ which was 1 ppb reduction from $4 \mathrm{ppb}(25 \%) ; 1 \mathrm{ppb}$ reduction observed from base case $25 \mathrm{ppb}$ for both $10 \%$ and $15 \%$ ratios at 8:00 on the same day; and $5^{\text {th }}$ June at 9:00 hr showed $1 \mathrm{ppb}$ reduction from $7 \mathrm{ppb}$ in the $10 \%$ and $15 \%$ ratio cases. The dominant sources in 2012 for $\mathrm{NO}_{\mathrm{x}}$ were On-road emissions in Harris County. Also, C556 located in the Houston Ship Channel (HSC) region where marine emissions have a higher impact than point sources from Fort Bend County. HSC is the largest complex of industrial sources of $\mathrm{NO}_{\mathrm{x}}$ and VOC in $\mathrm{HGB}$ area [9]. The wind flow passes WAP power plant goes to Houston downtown mostly, so it is unlikely that wind carries $\mathrm{NO}_{\mathrm{x}}$ to C556. But wind flow observed by Darby (2005) in higher ozone days in Houston often had offshore flow in the morning that switched to onshore flow in afternoon [32].

\subsection{Volatile Organic Compounds (VOC)}

This study added 14 different species $\left(\mathrm{ALD}_{2}, \mathrm{ALD}_{\mathrm{X}}, \mathrm{ETH}, \mathrm{ETHA}, \mathrm{ETOH}\right.$, FORM, IOLE, ISOP, MEOH, OLE, PAR, TERP, TOL, and XYL) of VOCs in VERDI to get VOC emissions. There is no significant variation of VOCs due to co-firing in ambient concentrations at C696 station, for the all-sources scenario, as presented in Figure 3. The variation was only observed during lower concentration days, only for four hours in the whole month. The maximum reduction was observed on $14^{\text {th }}$ June $(6 \%)$, which is only $1 \mathrm{ppb}$ reduction from a $16 \mathrm{ppb}$ base-case concentration. Considering only point + biogenic sources at C696, only six hours out of 720 hours, showed a reduction. The maximum drop was at 11:00 hr on $12^{\text {th }}$ June of $1 \mathrm{ppb}$ reduction from a $9 \mathrm{ppb}$ base-case, for both $10 \%$ and $15 \%$ co-firing. There is no reduction observed due to $5 \%$ co-firing, except at 13:00 hr on $2^{\text {nd }}$ June. At station C53, only one hour in the whole month showed a reduction $(1 \mathrm{ppb})$ in both cases for $15 \%$ co-firing. Co-firing of biomass in WAP has no effect on C556 station through the month, for both source scenario. Major contributors of VOC emission in HGB are area sources. In 2014, VOC emissions contribution from the area, mobile, and point sources are $61 \%, 23 \%$, and $16 \%$ respectively [33]. C53 located far from WAP in Harris County where mobile emissions much higher than Fort Bend County. The probable reason for negligible reduction may be a wind effect which carries the plume from WAP to C53 on this particular hour. C556 is dominated by VOC emission from Houston 


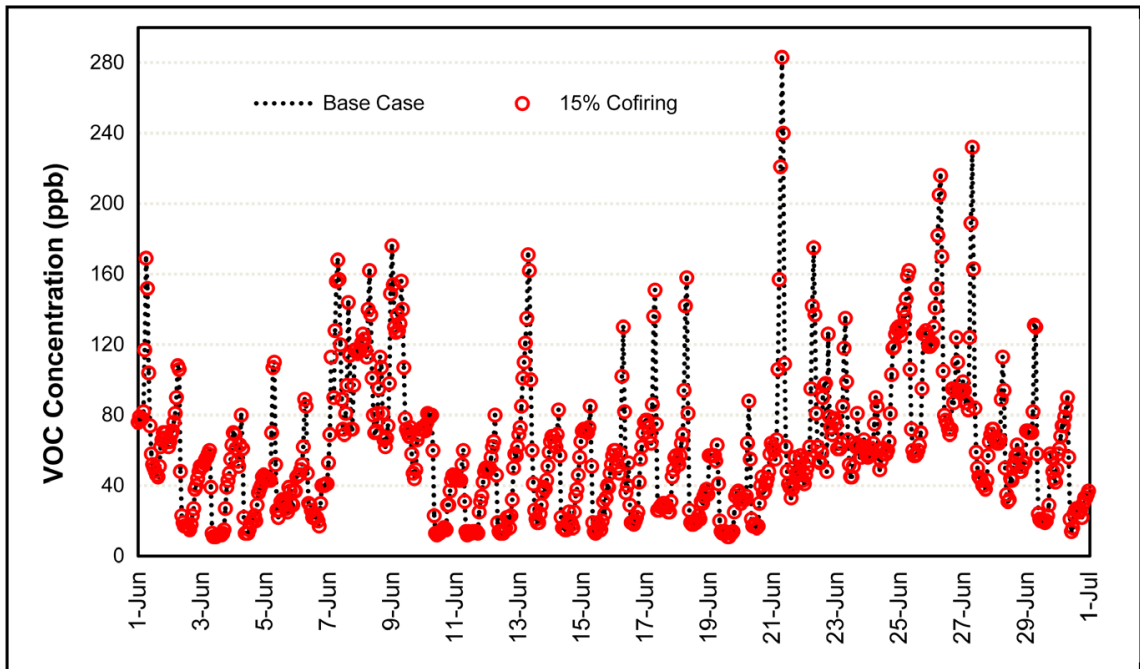

Figure 3. Reduction in $\mathrm{NO}_{\mathrm{X}}$ concentrations at C696 station due to co-firing (all-sources).

Ship Channel. In 2006, the VOC emission from WA Parish power plant and HSC was 0.5 tpd and 58.7 tpd respectively [9]. Temperature and wind account for $66 \%$ of the variation of VOCs from point sources [34].

\subsection{Ozone $\left(\mathrm{O}_{3}\right)$}

The maximum concentration during the June-2012 episode (105 ppb) was observed at 13:00 hr on $26^{\text {th }}$ June at C696 station for all-sources. The main reason behind maximum ozone on $26^{\text {th }}$ June is the high temperature and low cloud cover [35]. Biomass co-firing at WAP power plant has marginal reductions in ozone concentrations at the C696 location, and co-firing has effects on daily peak ozone concentrations as described in Figure 4. There are 23 different hours out of the 720 hours that show a reduction of ozone due to co-firing. The maximum percentage reduction (4.76\%) was observed on $3^{\text {rd }}$ June, but it is during the low ozone level. There are 7 hourly periods $\left(1^{\text {st }} J\right.$ June, $16: 00 \mathrm{hr} ; 6^{\text {th }}$ June 11:00 hr; $14^{\text {th }}$ June, 11:00 hr; $15^{\text {th }}$ June, 11:00 and 13:00 $\mathrm{hr} ; 18^{\text {th }}$ June, 12:00 $\mathrm{hr}$; and $27^{\text {th }}$ June, 13:00 hr) that co-firing resulted in reduction of daily maximum 1-hr ozone concentrations. $1 \mathrm{ppb}$ ozone reduction from peak can prevent $2-3$ deaths per year, indicating the significance of achieving marginal reduction [36]. Time series graph of concentrations for the only point and biogenic sources are presented in Figure 5. The maximum concentration for this sub-case ( $68 \mathrm{ppb}$ ) was observed at 13:00 $\mathrm{hr}$ on June $27^{\text {th }}$. Co-firing has a significant effect on air quality at C696, the maximum percentage $(6.25 \%)$ reduction was observed at $11^{\text {th }}$ June $(20: 00 \mathrm{hr})$ for $15 \% \mathrm{co}$-firing, ozone reduced to $15 \mathrm{ppb}$ from $16 \mathrm{ppb}$. Reduction of ozone was also detected on higher concentration days. On June $1^{\text {st }}(17: 00 \mathrm{hr}), 1$ ppb ozone reduction for $15 \%$ co-firing (base case ozone $62 \mathrm{ppb}$ ) was observed, and $1 \mathrm{ppb}$ decreases for both $10 \%$ and $15 \%$ co-firing cases was observed on $27^{\text {th }}$ June (12:00 hr). The ozone formation of C696 station is both $\mathrm{NO}_{\mathrm{x}}$ and VOC sensitive and is in a transitional state. So, the reduction in $\mathrm{O}_{3}$ at $\mathrm{C} 696$ may occur 


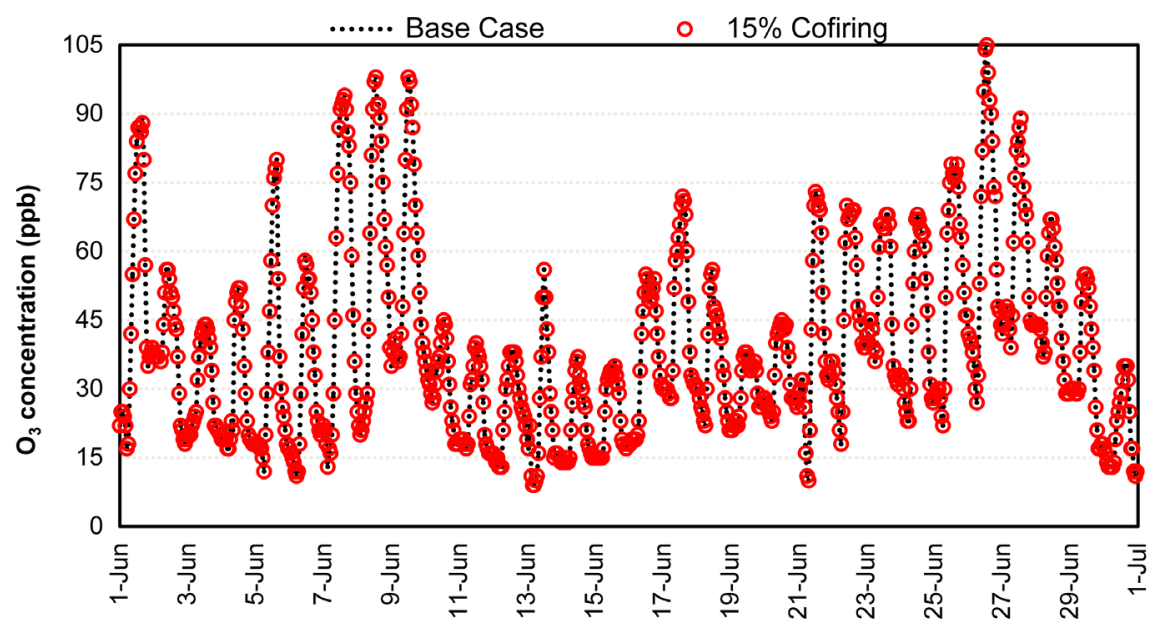

(a)

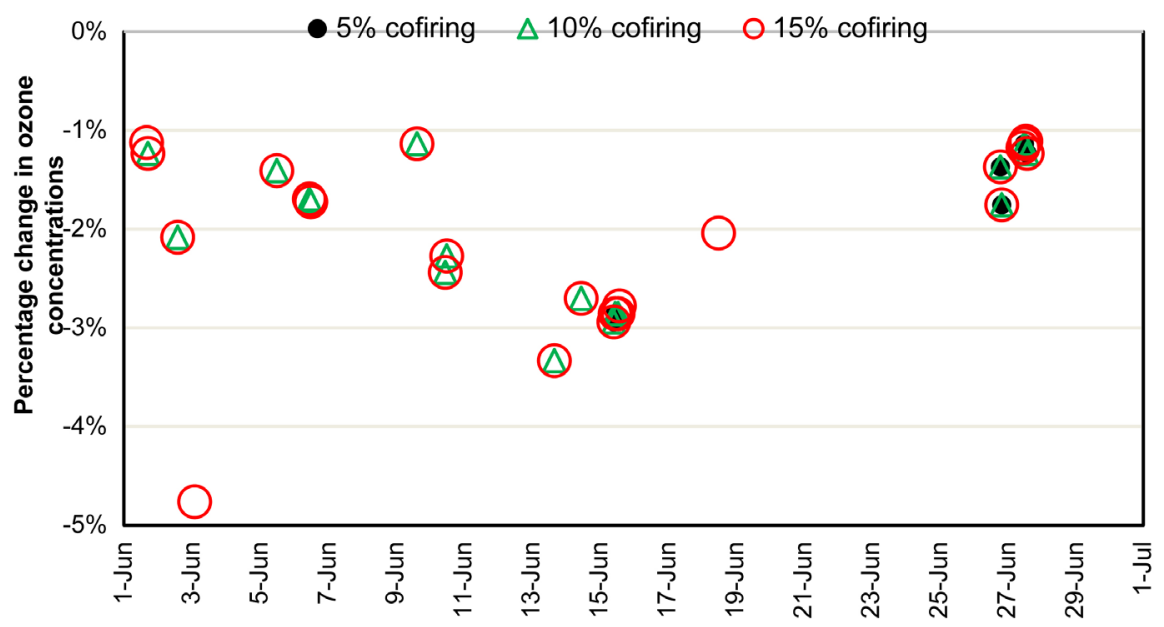

(b)

Figure 4. Effect of biomass co-firing on $\mathrm{O}_{3}$ concentrations at the $\mathrm{C} 696$ site (all-sources), (a): $\mathrm{O}_{3}$ concentrations for June 2012; (b): Percentage change due to co-firing.

due to the reduction of both $\mathrm{NO}_{\mathrm{x}}$ and VOC from the power plant. A study reported that $50 \%$ reduction of $\mathrm{NO}_{\mathrm{x}}$ from the $\mathrm{HGB}$ area has a huge impact on ozone in Houston and showed peak ozone reduced by $15 \%$ at air monitoring station located at the east of the HSC [37]. Also, previous studies found that ozone increased in areas where mobile and point sources dominate $\mathrm{NO}_{\mathrm{x}}$ emissions and regions with lower NO titration. Lin et al., (2005) observed that the peak hourly ozone decreases by $70 \mathrm{ppb}$ and $128 \mathrm{ppv}$ in Houston when $\mathrm{NO}_{\mathrm{x}}$ and VOC emissions from Texas point sources were ignored [38]. Also, 3\% ozone concentration difference occurred for $0.16 \%$ point source emission difference in HGB. Our study shows that a small but significant change of ozone at C696 station can be observed for very low reduction of VOC and $\mathrm{NO}_{\mathrm{x}}$ from point sources [39]. A report by TCEQ, noted that the peak ozone on September 8, 1993 reduced 1ppb from $187 \mathrm{ppb}$ in Houston due to complete removal of $\mathrm{NO}_{\mathrm{x}}$ emission from WAP [40]. 


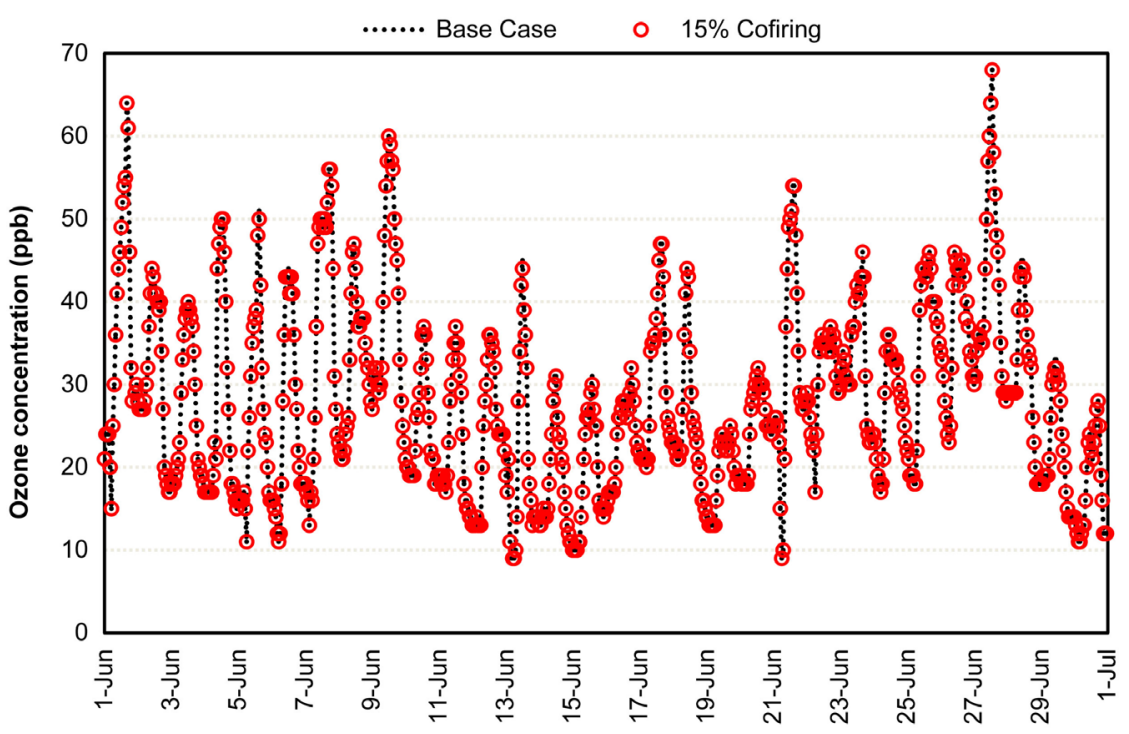

(a)

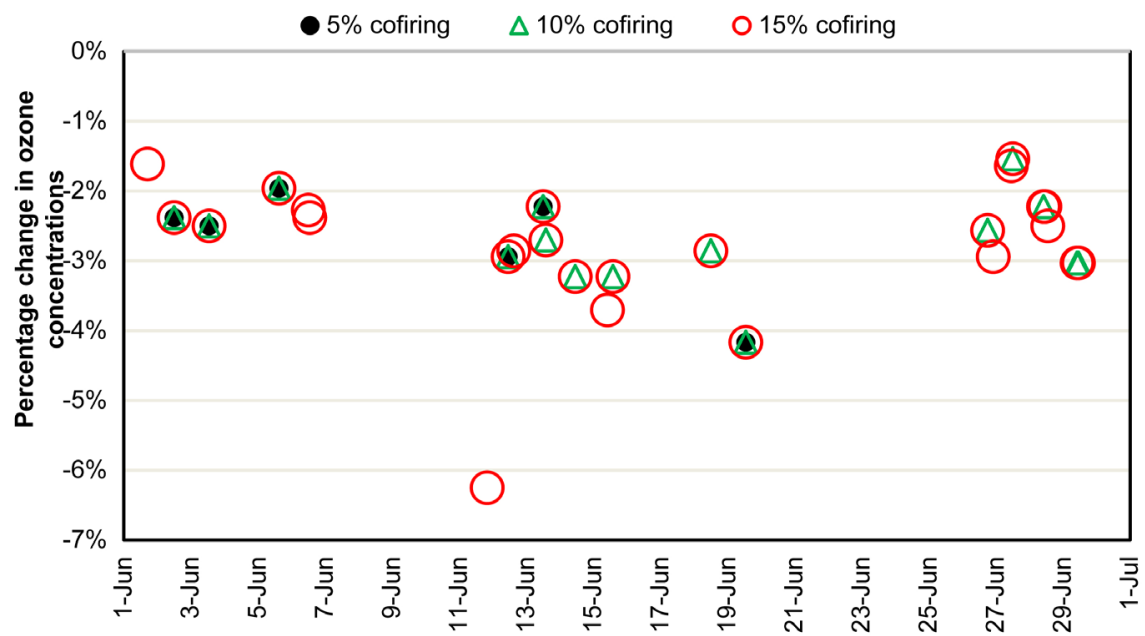

(b)

Figure 5. Effect of biomass co-firing on $\mathrm{O}_{3}$ concentrations at the $\mathrm{C} 696$ site (point + biogenic sources), (a): $\mathrm{O}_{3}$ concentrations for June 2012; (b): Percentage change due to co-firing.

From the CAMx results of $\mathrm{O}_{3}$ concentrations at $\mathrm{C} 53$ monitoring station for the base case and co-firing cases, percentage change in hourly ozone was analyzed and presented in Figure 6. The daily maximum occurred mostly during 11:00 to 14:00 hr, and the maximum during the month of June was observed on $26^{\text {th }}$ June (11:00 $\mathrm{hr}$ and 13:00 $\left.\mathrm{hr}\right)$. Though there were some hours where ozone reduction was observed due to co-firing at WAP, overall reduction was insignificant at C53, for all-sources. The maximum concentration for the month of June (64 ppb) was observed at 15:00 $\mathrm{hr}$ of $9^{\text {th }}$ June by considering the point and biogenic sources. The maximum percentage reduction $(3.33 \%)$ occurred at $13^{\text {th }}$ June (10:00 hr), the reduction is $1 \mathrm{ppb}$ for $5 \%, 10 \%$, and $15 \%$ co-firing ratios (base case concentration, $29 \mathrm{ppb}$ ). The changes due to $5 \%$ co-firing occurred 


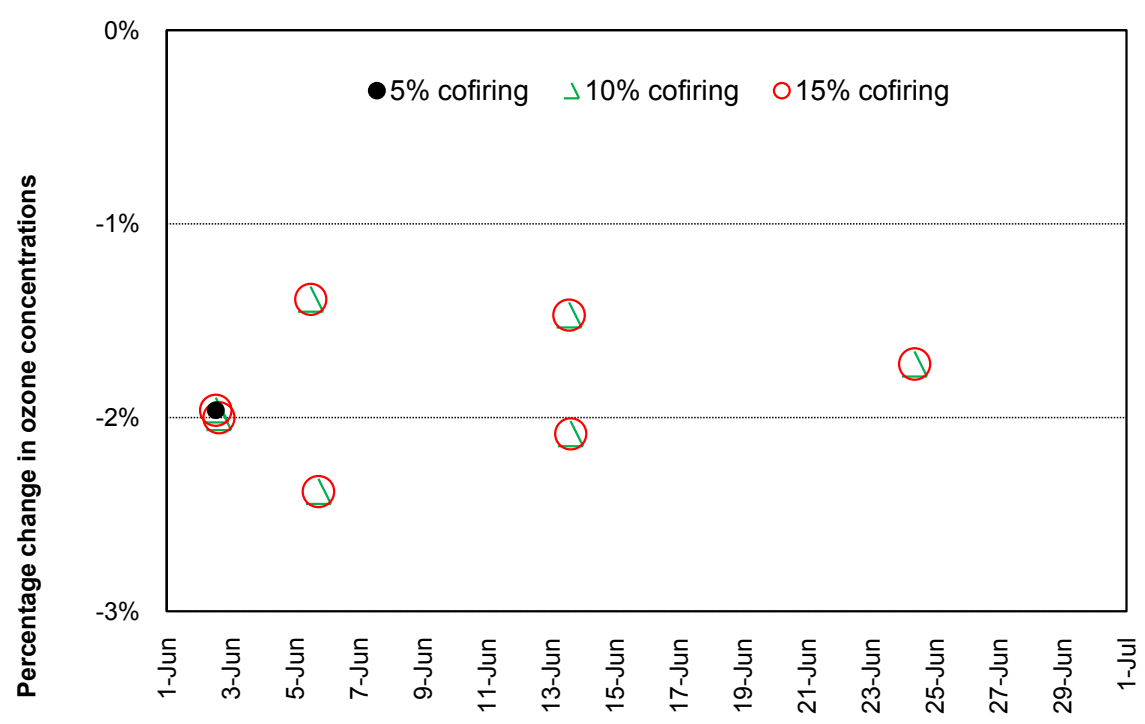

(a)

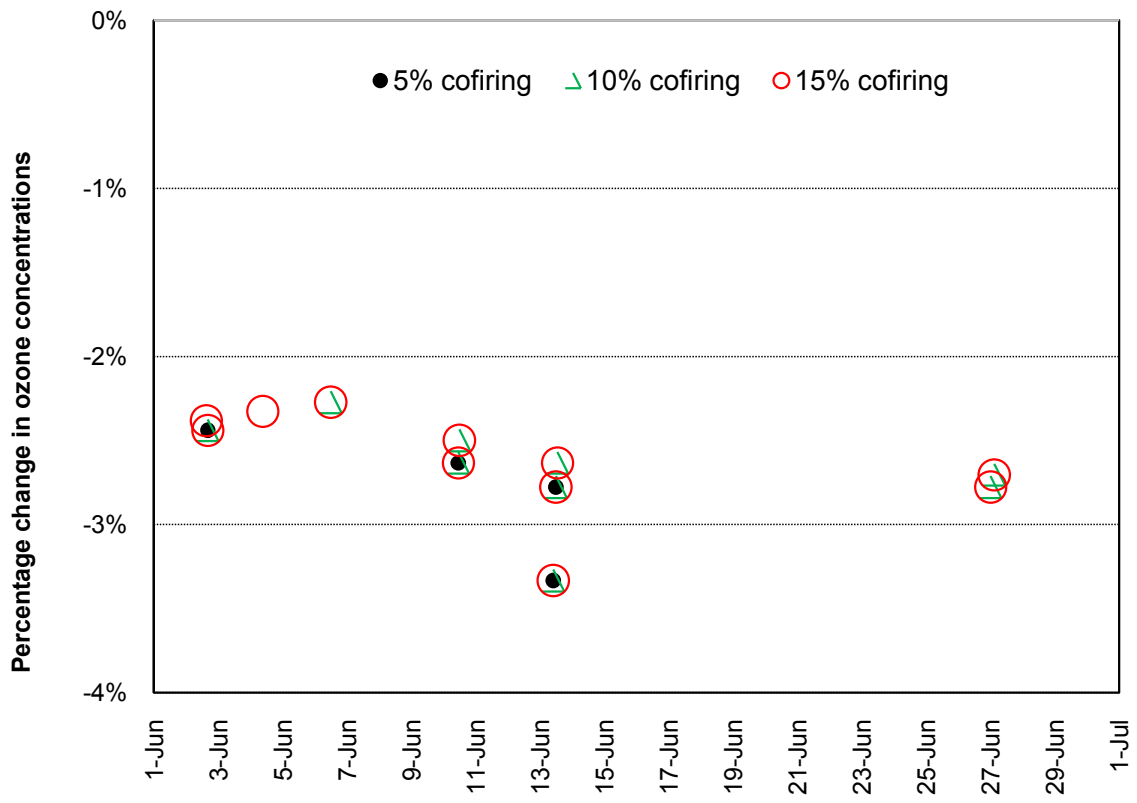

(b)

Figure 6. Percentage change in ozone concentrations at C53 in June 2012, due to co-firing; (a): all-sources; (b): point + biogenic sources.

several times in this case $\left(2^{\text {nd }}\right.$ June, $10^{\text {th }}$ June, and $13^{\text {th }}$ June). Biomass co-firing has not affected ozone levels during the peak concentration hours. Houston Bayland Park is mostly sensitive to VOC. So, the reduction of ozone might occur due to the reduction of VOC. The ozone concentrations did not show any significant changes due to co-firing at C556 for all-sources case. Only one incident of reduction was observed at 13:00 $\mathrm{hr}$ on $2^{\text {nd }}$ June where, $1 \mathrm{ppb}$ ozone reduced due to $15 \%$ co-firing, from a base case of $66 \mathrm{ppb}$. This reduction occurred on a relatively high ozone day. Only three hours out of 720 hours for the month of June showed a reduction for the point + biogenic case. The maximum percen- 
tage reduction (14\%) occurred on June $1^{\text {st }}(0: 00 \mathrm{hr})$, where actually $1 \mathrm{ppb}$ reduction noted from $7 \mathrm{ppb}$ (base case) for all three co-firing cases. The monitoring station that is located in the HSC area is mostly affected by VOCs. C556 has VOC sensitive ozone in most of the hours in June'12. High ozone concentrations in the HSC area are attributed to high concentrations of hydrocarbons [41]. So, the reduction of ozone precursors from WAP has a negligible effect at C556. One of the reasons for observing negligible effect at C556 is due to the westerly wind flow that carries plume from WAP at night and influences ozone only during subsequent days. But if the winds are very light, it creates stagnant conditions in the local area where the plume is generated. Also, nighttime transport of $\mathrm{NO}_{\mathrm{x}}$ reduces the concentration of $\mathrm{NO}_{\mathrm{x}}$. WA Parish plume of $\mathrm{NO}_{\mathrm{x}}$ losses $36 \%$ to $44 \%$ on average in overnight transport and the maximum reduction for $12 \mathrm{~h}$ of transport in darkness was $73 \%$, which lead to lower ozone formation due to $\mathrm{Pa}$ rish plume in downwind [42]. The reason for this was lack of enough $\mathrm{NO}_{\mathrm{x}}$ at plume to titrate background ozone which led to rapid nighttime oxidation of $\mathrm{NO}_{2}$ during downwind transport during that particular simulation period.

C556 air monitoring station is located in Harris County and nearby the Houston Ship Channel. Time series graph for ozone concentration at C556 is presented in Figure 7. When all-sources were considered, the maximum concentration for June month was observed at 15:00 hr on $26^{\text {th }}$ June (99 ppb). The daily peak occurred during 12:00 to 14:00 $\mathrm{hr}$ on most of the days of the month, and June $20^{\text {th }}$ the peak occurred at 23:00 $\mathrm{hr}$. The diurnal variations followed the same trend as other locations, lower concentrations observed in the early morning. The ozone concentrations did not show any significant changes due to co-firing. Only one incident of reduction was observed at 13:00 hr on $2^{\text {nd }}$ June where, $1 \mathrm{ppb}$ ozone reduced due to $15 \%$ co-firing, from a base case of $66 \mathrm{ppb}$. For the point + biogenic sources scenario, the maximum concentration was observed on $26^{\text {th }}$ June $(9: 00 \mathrm{hr})(72 \mathrm{ppb})$. The peak ozone in the first 10 days of the month was observed on $5^{\text {th }}$ June and for the mid-10 days on $17^{\text {th }}$ June, the peaks are $55 \mathrm{ppb}$ and $47 \mathrm{ppb}$ respectively. In mid-10 days the daily peaks of ozone concentrations are relatively lower than other parts of the month. The lower concentration occurred during midnight to morning in most of the days. There is no significant reduction of concentrations at this location due to co-firing. Only three hours out of 720 hours for the month of June show reduction. The maximum percentage reduction (14\%) occurred on June $1^{\text {st }}(0: 00 \mathrm{hr})$, where actually $1 \mathrm{ppb}$ reduction noted from $7 \mathrm{ppb}$ (base case) for all three co-firing cases. The other two hours where the reduction was observed were at $5^{\text {th }}$ June 12:00 and 13:00 hr, where $1 \mathrm{ppb}$ reduction observed from $55 \mathrm{ppb}$ and $50 \mathrm{ppb}$ respectively.

\subsection{Sulfur Dioxide $\left(\mathrm{SO}_{2}\right)$}

Lower concentrations of $\mathrm{SO}_{2}$ were observed during midnight to early morning throughout the month, except June 7. The peak $\mathrm{SO}_{2}$ concentration ( $34 \mathrm{ppb}$ ) of June 2012 observed on $13^{\text {th }}$ June, 11:00 hr, as shown in Figure 8. The daily 


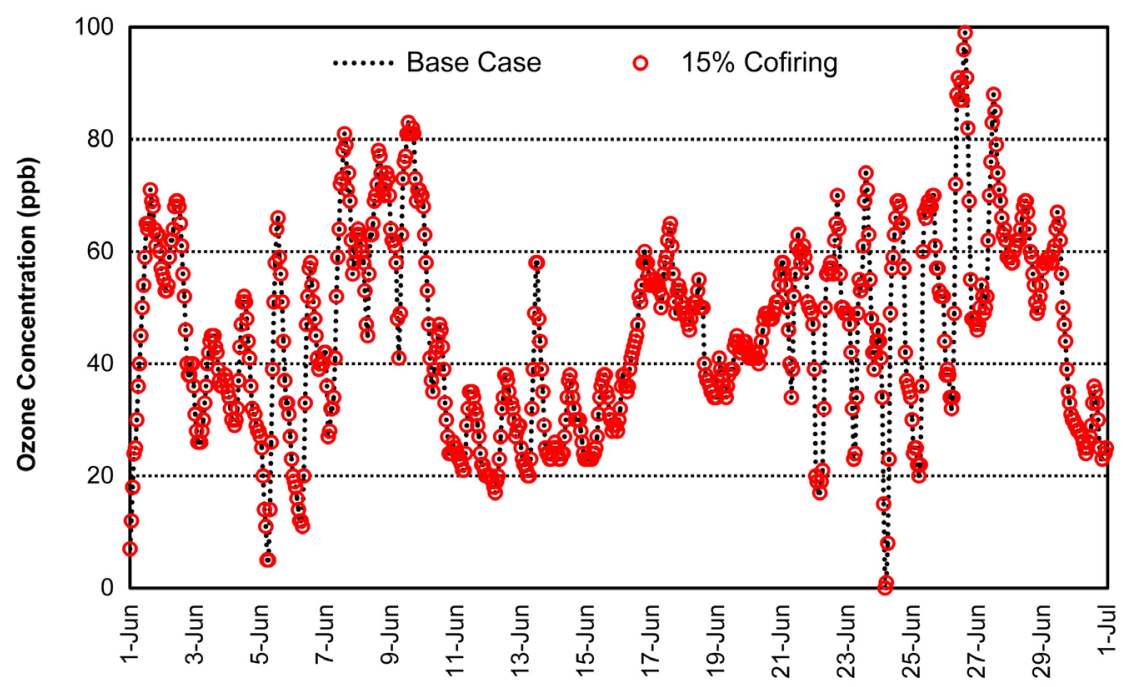

(a)

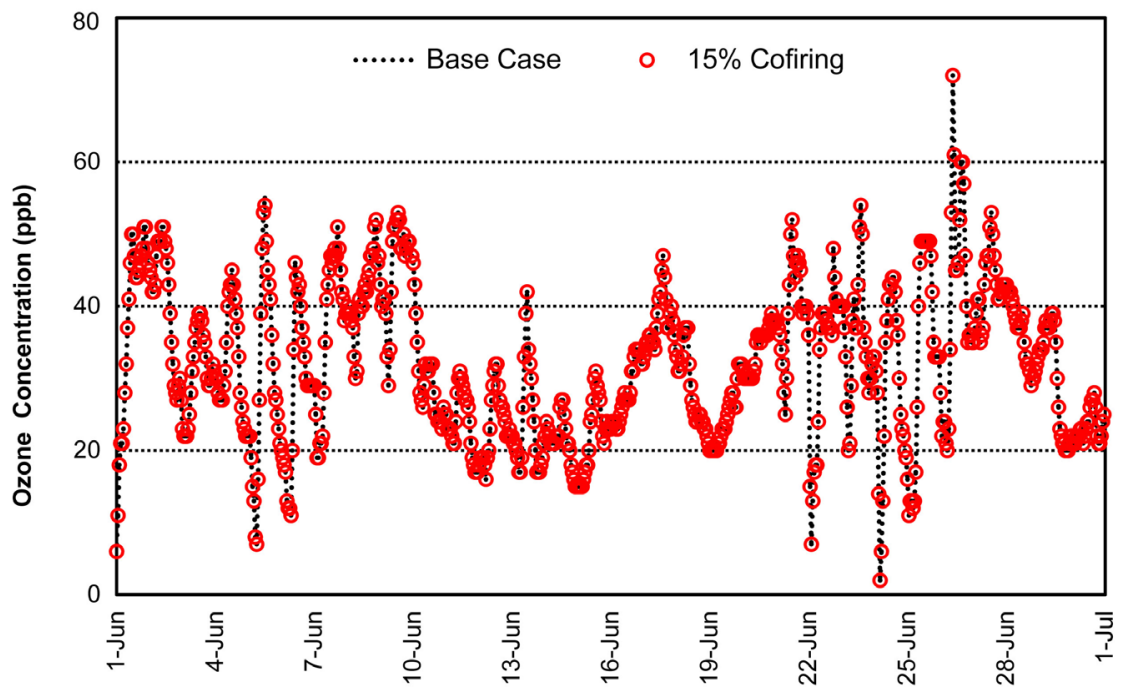

(b)

Figure 7. Effect of biomass co-firing on $\mathrm{O}_{3}$ concentrations at C556 (a): all-sources; (b): point + biogenic sources.

maximum was observed in the mornings between 7:00 to 11:00 $\mathrm{hr}$ for most of the days. Ambient $\mathrm{SO}_{2}$ concentrations at $\mathrm{C} 696$ air monitoring station were significantly affected due to co-firing of biomass with coal at the WAP power plant. The maximum reduction (25\%) of $\mathrm{SO}_{2}$ observed on $5^{\text {th }}$ June in the first 10 days of month, but it is in lower concentration day. Sulfur dioxide concentrations also show significant drop during higher concentration days also. On June 4, 8:00 hr the peak $\mathrm{SO}_{2}$ in first 10 days, due to co-firing of $5 \%, 10 \%$, and $15 \%$ ratio the concentration reduces by $5 \%, 5 \%$, and $10 \%$ respectively (Figure $8(\mathrm{~b})$ ). The peak for the whole month was observed at June $13^{\text {th }}$; concentrations show a gentle decrease in this day, which is $9 \%$ and $12 \%$ for $10 \%$ and $15 \%$ co-firing respectively. In higher concentration days, $5 \%$ co-firing does not have an impact mostly. Almost all of the higher concentration days observed a drop of concentration due 


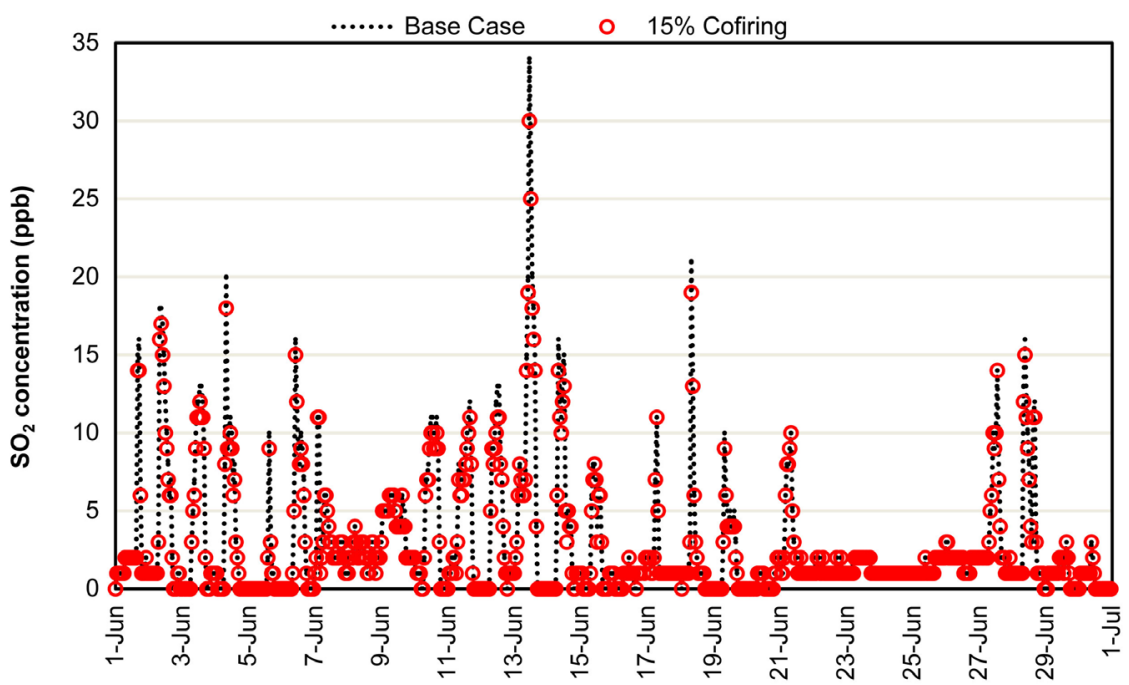

(a)

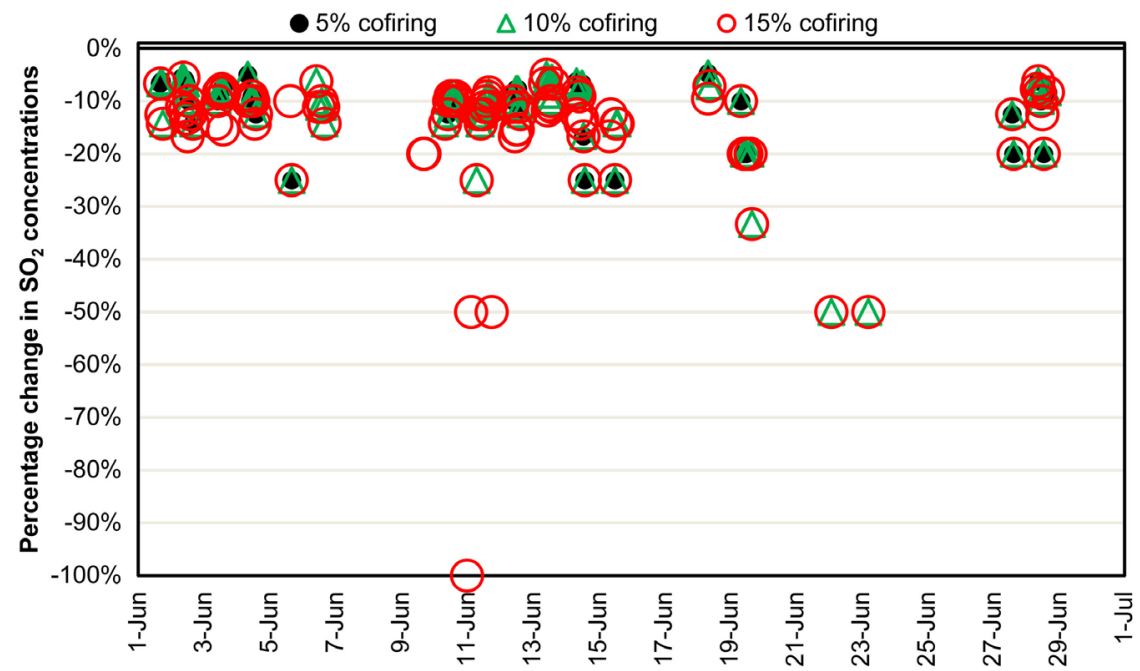

(b)

Figure 8. Effect of biomass co-firing on $\mathrm{SO}_{2}$ concentrations at $\mathrm{C696}$ (a): Time-series graph; (b): Percentage change due to co-firing.

to co-firing while lowest $\mathrm{SO}_{2}$ concentration didn't show a frequent drop. For the point + biogenic sources, the maximum concentration (30 ppb) was observed at 11:00 $\mathrm{hr}$ on June $13^{\text {th }}$. It is the same time where peak occurred due to all source case also. The daily maximum observed for all days during daytime except June $7^{\text {th }}$ where daily peak shows at 2:00 hr. The reduction of $\mathrm{SO}_{2}$ concentration observed for almost all the high concentration hours with less number of hours counted that have a lower concentration. The reduction in peak concentration day ( $13^{\text {th }}$ June) is $3 \mathrm{ppb}$ ( $32 \mathrm{ppb}$ to $29 \mathrm{ppb}$ ) for $15 \%$ co-firing, $2 \mathrm{ppb}$ for $10 \%$, and $1 \mathrm{ppb}$ for $5 \%$ co-firing.

Fossil fuel combustion is the largest source of $\mathrm{SO}_{2}$ emissions. Power plants emit more than $70 \%$ of $\mathrm{SO}_{2}$ in Houston, other industrial facilities contribute around $20 \%$. TCEQ studied 7 major point source emissions sources in HGB area 
where WAP parish plant had highest $(167.1 \mathrm{tpd}) \mathrm{SO}_{2}$ emission in 2006 that was around two times greater than all other six sources [9]. Emissions from non-road sources in Fort Bend County were relatively lower (0.01 tpd) in 2012, and area sources emited $0.28 \mathrm{tpd}$, which was not significant [43]. There are no significant sources of $\mathrm{SO}_{2}$ in nearby WAP power plant. Since $\mathrm{C} 696$ is nearby WAP power plant, Power plant emission has a great impact on air monitoring station in both cases. The highest $\mathrm{SO}_{2}$ days affected most because of WAP is probably responsible for high $\mathrm{SO}_{2}$ in this station. Also, wind direction and speed plays a vital role for highest concentration days. A study by TCEQ shows that Croquet monitoring station located at $22.4 \mathrm{~km}$ north-northeast of Parish is heavily affected when the wind blows towards station from WAP [27]. There are a few reduction hours observed in C556 for all-sources case. The maximum reduction (13\%) observed at 12:00 hr and 11:00 hr on $5^{\text {th }}$ June and $6^{\text {th }}$ June for $15 \%$ co-firing. The other time periods where the reduction was observed are at 7:00, 8:00, 9:00 hr on June $5^{\text {th }}$ and 9:00 $\mathrm{hr}$ on June $6^{\text {th }}$, all these hours indicating a 1 ppb reduction for $10 \%$ and $15 \%$ co-firing. No reduction observed for $5 \%$ co-firing. The reasons behind insignificant reduction that C556 located at HSC where ship emissions have a dominant impact. For point + biogenic case, the peak $\mathrm{SO}_{2}$ concentration observed at 0:00 hr on June $1^{\text {st }}$ and the value is $23 \mathrm{ppb}$ and $1 \mathrm{ppb}$ reduction observed in that hour for $10 \%$ and $15 \%$ co-firing cases. There is no big drop in concentration overall except at 10:00 $\mathrm{hr}$ on $5^{\text {th }}$ June where $1 \mathrm{ppb}$ dropped from $4 \mathrm{ppb}$ for both $10 \%$ and 15\% co-firing ratio which is a $25 \%$ reduction.; at 7:00 hr, 8:00 hr in same day $1 \mathrm{ppb}$ drop observed for same co-firing cases. Also, $1 \mathrm{ppb}$ reduction observed at 9:00 and 10:00 $\mathrm{hr}$ on $6^{\text {th }}$ June.

\subsection{Carbon Monoxide (CO)}

Figure 9 describes the percentage reductions observed in $\mathrm{CO}$ concentrations, due to co-firing considering all-sources. Co-firing has a negligible effect on $\mathrm{CO}$ concentrations at the C696 station. There is no change in emissions for the whole month, due to 5\% co-firing, except on June 2 and 12 at 9:00 and 10:00 hr of $0.78 \%$ and $0.82 \%$ respectively. For $10 \%$ co-firing, there are changes in 16 hourly data points out of 720 hours, at a maximum reduction of $1.04 \%$ on $4^{\text {th }}$ June. For the $15 \%$ co-firing case, a total of 27 hourly data points show a reduction, with a maximum reduction similar to $10 \%$ case. There is no reduction observed during the peak $\mathrm{CO}$ concentration hours. Any reductions which were only observed during lower concentration hours would not affect the CO levels in view of public health or welfare. A comparison of the base case and co-firing cases doesn't indicate a significant difference due to limiting the source categories to point + biogenic sources. The maximum reduction of $10.23 \%$, on June $5^{\text {th }}$ at $15: 00 \mathrm{hr}$ for $15 \%$ co-firing ratio, CO reduces from $88 \mathrm{ppb}$ to $79 \mathrm{ppb}$ at this particular hour. The maximum reduction of $2 \% \mathrm{CO}$, for $5 \%$ co-firing was observed on June 1, 21:00 hr. All of the reductions occurred when CO was less than 150 ppb. C696 is the closest air monitoring station to WAP, and Fort Bend 


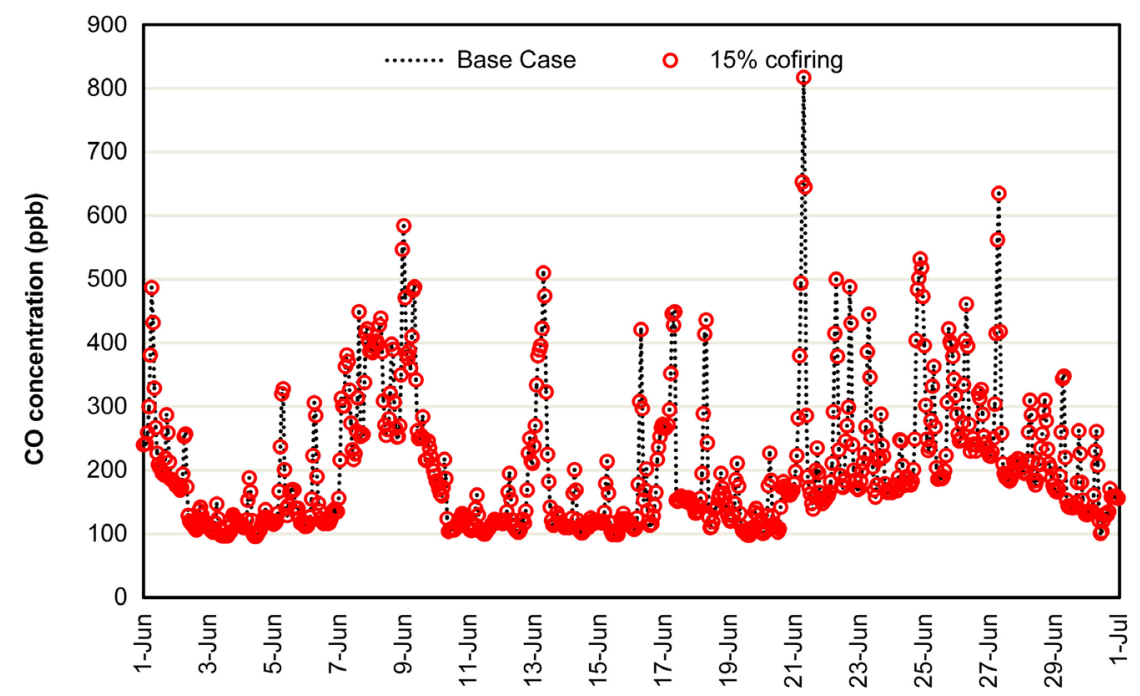

(a)

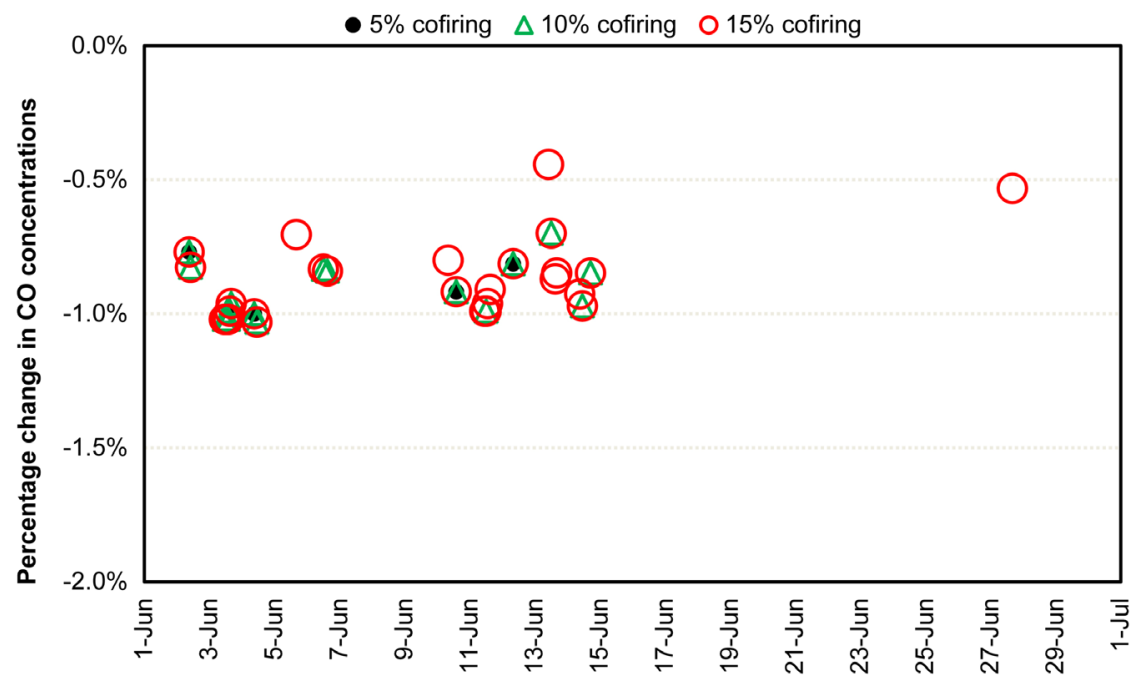

(b)

Figure 9. Effect of biomass co-firing on CO concentration at C696 (all-sources) [(a): CO concentration; (b): Percentage change].

County has lower point source emissions (WAP excluded), than Harris County. When all-sources were considered, modeling results suggest that reduction in $\mathrm{CO}$ levels would be significantly lower compared to the case where only point and biogenic sources are considered. This can be explained by the fact that mobile sources emit huge quantities of $\mathrm{CO}$ in composition to point sources, thereby magnifying any effect of co-firing at WAP on the CO levels observed at C696 station. Also, meteorological factors greatly influence pollutant concentrations, minimizing the effects of co-firing. The co-firing of biomass with coal in WAP does not have any notable effect on C53 and C556 air monitoring station in both cases. Only on $10^{\text {th }}$ June 7:00 $\mathrm{hr}$, a very small reduction of $1 \mathrm{ppb}$ from $503 \mathrm{ppb}$, was observed for $10 \%$ and $15 \%$ co-firing. C53 is located in highly populated area which is greatly affected by mobile sources rather than electricity generation fa- 
cilities and is located $27.64 \mathrm{~km}$ far from WAP. Friedfeld et al., (2002) reported that $90 \%$ of total CO came from mobile sources whereas only $8 \%$ is due to all stationary sources in HGB area for 1999 [44]. So, a small percentage of CO changes in WAP do not have a significant effect on C53 location. Area sources emit almost 10 times CO in Harris County than Fort Bend County [27]. C556, located in Harris County and non-road emissions of $\mathrm{CO}$ are around 13 times higher than Fort Bend County, where WAP is located. So, this small reduction of $\mathrm{CO}$ in WAP due to co-firing does not necessarily affect C556 air quality. Table 4 summarizes the number of reductions in daily maximum $1 \mathrm{hr}$ concentrations of all pollutants that were observed at the C696 monitoring station, during the month of June 2012.

\section{Conclusion}

This study evaluated the air quality impact of biomass co-firing with coal at three monitoring sites (C696, C53, C556) in the HGB area with CAMx simulations for the month of June 2012. Co-firing ratios of 5\%, 10\%, and 15\% (energy-basis) of forest residue at WAP were considered, and combustion stage emissions were modified in the point source AFS file for EGUs, as input to CAMx simulations. Two source scenarios (all-sources, point + biogenic sources) were considered and significant reduction of $\mathrm{SO}_{2}$ and $\mathrm{O}_{3}$ was observed for the $10 \%$ and $15 \%$ co-firing ratios at the monitoring station (C696) closest to the WAP plant. The maximum reduction in ambient ozone concentrations was observed for $15 \%$ co-firing, around $4.7 \%$ and $6.3 \%$ for all-sources and point + biogenic sources scenarios respectively, on high concentration days. The ambient concentrations at monitoring stations far from WAP were not affected significantly by emissions reduction from co-firing. The maximum reduction observed for $\mathrm{SO}_{2}$ at the $\mathrm{C} 556$ station was estimated to be $13 \%$ (all-source) and 25\% (point + bio), for the $15 \%$ co-firing ratio, indicating the importance of $\mathrm{WAP} \mathrm{SO}_{2}$ control systems for the HGB region. Ozone sensitivity varies with location, and the influence of WAP to VOC levels is negligible at all stations. The results indicate that biomass co-firing at WAP plant would only impact ambient concentrations of ozone and $\mathrm{SO}_{2}$ at the $\mathrm{C} 696$ station, which is the closest to the plant, and this reduction is more pronounced when considering (point + biogenic) sources

Table 4. Number of reductions in daily maximum 1-hr concentrations at C696 station, for June 2012.

\begin{tabular}{ccc}
\hline Air Pollutant & All-sources & Point + Biogenic \\
\hline $\mathrm{SO}_{2}$ & $17 / 30$ & $19 / 30$ \\
$\mathrm{NO}_{\mathrm{x}}$ & - & $9 / 30$ \\
$\mathrm{VOC}$ & - & - \\
$\mathrm{CO}$ & - & $1 / 30$ \\
$\mathrm{O}_{3}$ & $5 / 30$ & $9 / 30$ \\
\hline
\end{tabular}


instead of all-sources. The overall results from this study indicate that biomass co-firing at WAP in isolation, would not lead to a significant reduction in ozone concentrations in the region, especially during periods of peak ozone levels. Biomass co-firing should be combined with emission controls for the area and mobile sources in order to observe any further significant improvement. Certain limitations of the current study, such as duration of CAMx simulations and non-inclusion of meteorological fluctuations should be considered while interpreting the results described in this study.

\section{Acknowledgements}

This research is supported by the National Science Foundation (NSF), through the Center for Energy and Environmental Sustainability (CEES), an NSF CREST Center (Award \# 1036593). The technical content of this paper is solely the responsibility of the authors.

\section{Conflicts of Interest}

The authors declare no conflicts of interest regarding the publication of this paper.

\section{References}

[1] Kleinman, L.I., Daum, P.H., Imre, D., Lee, Y.N., Nunnermacker, L.J., Springston, S.R., Weinstein-Lloyd, J. and Rudolph, J. (2002) Ozone Production Rate and Hydrocarbon Reactivity in 5 Urban Areas: A Cause of High Ozone Concentration in Houston. Geophysical Research Letters, 29, 105-1-105-4.

[2] Kleinman, L.I., Daum, P.H., Imre, D., Lee, Y.N., Nunnermacker, L.J., Springston, S.R., Weinstein-Lloyd, J. and Rudolph, J. (2003) Correction to "Ozone Production Rate and Hydrocarbon Reactivity in 5 Urban Areas: A Cause of High Ozone Concentration in Houston". Geophysical Research Letters, 30. https://doi.org/10.1029/2003GL017485

[3] TCEQ, Houston-Galveston-Brazoria Nonattainment Area Ozone Conceptual Model 2009, Texas Commission on Environmental Quality: Austin, TX.

[4] EPA (2017) Nonattainment Areas for Criteria Pollutants (Green Book). https://www3.epa.gov/airquality/greenbook/hbtc.html

[5] Crutzen, P.J. (1974) Photochemical Reactions Initiated by and Influencing Ozone in Unpolluted Tropospheric Air. Tellus, 26, 47-57. https://doi.org/10.3402/tellusa.v26i1-2.9736

[6] Sillman, S. (1999) The Relation between Ozone, $\mathrm{NO}_{\mathrm{x}}$ and Hydrocarbons in Urban and Polluted Rural Environments. Atmospheric Environment, 33, 1821-1845. https://doi.org/10.1016/S1352-2310(98)00345-8

[7] Finlayson-Pitts, B.J. and Pitts, J.N. (1997) Tropospheric Air Pollution: Ozone, Airborne Toxics, Polycyclic Aromatic Hydrocarbons, and Particles. Science, 276, 1045-1051. https://doi.org/10.1126/science.276.5315.1045

[8] Atkinson, R. (2000) Atmospheric Chemistry of VOCs and $\mathrm{NO}_{\mathrm{x}}$. Atmospheric Environment, 34, 2063-2101. https://doi.org/10.1016/S1352-2310(99)00460-4

[9] Washenfelder, R.A., Trainer, M., Frost, G.J., Ryerson, T.B., Atlas, E.L., Gouw, J.A.D., Flocke, F.M., Fried, A., Holloway, J.S., Parrish, D.D., Peischl, J., Richter, D., Schauffler, S.M., Walega, J.G., Warneke, C., Weibring, P. and Zheng, W. (2010) 
Characterization of $\mathrm{NO}_{\mathrm{x}}, \mathrm{SO}_{2}$, Ethene, and Propene from Industrial Emission Sources in Houston, Texas. Journal of Geophysical Research: Atmospheres, 115. https://doi.org/10.1029/2009JD013645

[10] He, H., Hembeck, L., Hosley, K.M., Canty, T.P., Salawitch, R.J. and Dickerson, R.R. (2013) High Ozone Concentrations on Hot Days: The Role of Electric Power Demand and $\mathrm{NO}_{\mathrm{x}}$ Emissions. Geophysical Research Letters, 40, 5291-5294. https://doi.org/10.1002/grl.50967

[11] Flues, M., Hama, P., Lemes, M.J.L., Dantas, E.S.K. and Fornaro, A. (2002) Evaluation of the Rainwater Acidity of a Rural Region Due to a Coal-Fired Power Plant in Brazil. Atmospheric Environment, 36, 2397-2404. https://doi.org/10.1016/S1352-2310(01)00563-5

[12] Brock, C.A., Trainer, M., Ryerson, T.B., Neuman, J.A., Parrish, D.D., Holloway, J.S., Nicks, D.K., Frost, G.J., Hübler, G., Fehsenfeld, F.C., Wilson, J.C., Reeves, J.M., Lafleur, B.G., Hilbert, H., Atlas, E.L., Donnelly, S.G., Schauffler, S.M., Stroud, V.R. and Wiedinmyer, C. (2003) Particle Growth in Urban and Industrial Plumes in Texas. Journal of Geophysical Research: Atmospheres, 108. https://doi.org/10.1029/2002JD002746

[13] Srivastava, R.K., Miller, C.A., Erickson, C. and Jambhekar, R. (2004) Emissions of Sulfur Trioxide from Coal-Fired Power Plants. Journal of the Air \& Waste Management Association, 54, 750-762. https://doi.org/10.1080/10473289.2004.10470943

[14] Zhou, W., Cohan, D.S., Pinder, R.W., Neuman, J.A., Holloway, J.S., Peischl, J., Ryerson, T.B., Nowak, J.B., Flocke, F. and Zheng, W.G. (2012) Observation and Modeling of the Evolution of Texas Power Plant Plumes. Atmospheric Chemistry and Physics, 12, 455-468. https://doi.org/10.5194/acp-12-455-2012

[15] Cowling, E.B., Furiness, C., Dimitriades, B. and Parrish, D. (2007) Final Rapid Science Synthesis Report: Findings from the Second Texas Air Quality Study (TexAQS II) 2007, Texas Commission on Environmental Quality.

[16] Chipindula, J., Botlaguduru, V., Du, H., Kommalapati, R. and Huque, Z. (2018) Life Cycle Environmental Impact of Onshore and Offshore Wind Farms in Texas. Sustainability, 10, 2022. https://doi.org/10.3390/su10062022

[17] Demirbaş, A. (2003) Sustainable Cofiring of Biomass with Coal. Energy Conversion and Management, 44, 1465-1479. https://doi.org/10.1016/S0196-8904(02)00144-9

[18] Hus, P.J. and Tillman, D.A. (2000) Cofiring Multiple Opportunity Fuels with Coal at Bailly Generating Station. Biomass and Bioenergy, 19, 385-394. https://doi.org/10.1016/S0961-9534(00)00050-7

[19] Kommalapati, R., Hossan, I., Botlaguduru, V., Du, H. and Huque, Z. (2018) Life Cycle Environmental Impact of Biomass Co-Firing with Coal at a Power Plant in the Greater Houston Area. Sustainability, 10, 2193.

https://doi.org/10.3390/su10072193

[20] Agriculture T.D.O. (2010) Texas Bioenergy 2010 Status Report. Texas Department of Agriculture, Austin.

[21] Dwivedi, P., Bailis, R. and Khanna, M. (2014) Is Use of Both Pulpwood and Logging Residues Instead of Only Logging Residues for Bioenergy Development a Viable Carbon Mitigation Strategy? BioEnergy Research, 7, 217-231. https://doi.org/10.1007/s12155-013-9362-Z

[22] Tillman, D.A. (2000) Cofiring Benefits for Coal and Biomass. Biomass and Bioenergy, 19, 363-364. https://doi.org/10.1016/S0961-9534(00)00048-9

[23] Tillman, D.A. (2000) Biomass Cofiring: The Technology, the Experience, the Combustion Consequences. Biomass and Bioenergy, 19, 365-384. 
https://doi.org/10.1016/S0961-9534(00)00049-0

[24] David Kline, T.H. and Vanderlan, C. (1998) The Treatment of Biomass Fuels in Carbon Emissions Trading Systems. Center for Clean Air Policy.

[25] EIA U.S. (2016) Southern States Lead Growth in Biomass Electricity Generation. Today in Energy. https://www.eia.gov/todayinenergy/detail.php?id=26392

[26] Environ, R. (2016) User's Guide Comprehensive Air Quality Model with Extensions. Version 6.3, Novato.

[27] Hossan, I. (2017) Impact of Biomass Cofiring with Coal on the Air Quality of Greater Houston Area: Life Cycle Assessment and Photochemical Modeling, in Engineering. Prairie View A\&M University, Prairie View.

[28] TCEQ (2012).

https://www.tceq.texas.gov/airquality/airmod/data/tx2012

[29] TCEQ (2012).

ftp://amdaftp.tceq.texas.gov/TX/camx/2012/bc12_12xxx.r6a_r4a.2012_wrf371_p2m a_i2mSNgqsfc0_f/

[30] Lonsdale, C.R., Stevens, R.G., Brock, C.A., Makar, P.A., Knipping, E.M. and Pierce, J.R. (2012) The Effect of Coal-Fired Power-Plant $\mathrm{SO}_{2}$ and $\mathrm{NO}_{\mathrm{x}}$ Control Technologies on Aerosol Nucleation in the Source Plumes. Atmospheric Chemistry and Physics, 12, 11519-11531. https://doi.org/10.5194/acp-12-11519-2012

[31] Gorai, A.K., Tuluri, F., Tchounwou, P.B. and Ambinakudige, S. (2015) Influence of Local Meteorology and $\mathrm{NO}_{2}$ Conditions on Ground-Level Ozone Concentrations in the Eastern Part of Texas, USA. Air Quality, Atmosphere, \& Health, 8, 81-96. https://doi.org/10.1007/s11869-014-0276-5

[32] Darby, L.S. (2005) Cluster Analysis of Surface Winds in Houston, Texas, and the Impact of Wind Patterns on Ozone. Journal of Applied Meteorology, 44, 1788-1806. https://doi.org/10.1175/JAM2320.1

[33] TCEQ. Texas Emission Sources-A Graphical Representation. https://www.tceq.texas.gov/airquality/areasource/texas-emissions-graphical-represe ntation

[34] Cetin, E., Odabasi, M. and Seyfioglu, R. (2003) Ambient Volatile Organic Compound (VOC) Concentrations around a Petrochemical Complex and a Petroleum Refinery. Science of the Total Environment, 312, 103-112. https://doi.org/10.1016/S0048-9697(03)00197-9

[35] U.S. Air Quality, The Smoke Blog (2012). http://alg.umbc.edu/usaq/archives/2012_06.html

[36] Governments C.A.C.o. (2014) EPA's Ozone Standard Proposal and How It Could Affect Central Texas, in Fact Sheet. Austin.

[37] Jiang, G. and Fast, J.D. (2004) Modeling the Effects of VOC and NOX Emission Sources on Ozone Formation in Houston during the TexAQS 2000 Field Campaign. Atmospheric Environment, 38, 5071-5085. https://doi.org/10.1016/j.atmosenv.2004.06.012

[38] Lin, C.-J., Ho, T.C., Chu, H.-W., Yang, H., Chandru, S., Krishnarajanagar, N., Chiou, P. and Hopper, J.R. (2005) Sensitivity Analysis of Ground-Level Ozone Concentration to Emission Changes in Two Urban Regions of Southeast Texas. Journal of Environmental Management, 75, 315-323. https://doi.org/10.1016/j.jenvman.2004.09.012

[39] Sarker, S., Liang, Z., Huque, Z. and Kommalapati, R.R. (2013) Impact of Point Sources Emissions on Ozone Formation for Houston Galveston. International 
Journal of Ecology and Environmental Sciences, 2.

[40] TCEQ (2001) An Investigation of CAMx Modeling Issues with Sensitivity Simulations for the September 6-11, 1993 Ozone Episode in the HGB Area. Texas Commission on Environmental Quality, Austin.

[41] Parrish, D.D., Allen, D.T., Bates, T.S., Estes, M., Fehsenfeld, F.C., Feingold, G., Ferrare, R., Hardesty, R.M., Meagher, J.F., Nielsen-Gammon, J.W., Pierce, R.B., Ryerson, T.B., Seinfeld, J.H. and Williams, E.J. (2009) Overview of the Second Texas Air Quality Study (TexAQS II) and the Gulf of Mexico Atmospheric Composition and Climate Study (GoMACCS). Journal of Geophysical Research: Atmospheres, 114, D00F13.

[42] David Allen, E.M.-B. and McGaughey, G. (2018) State of the Science of Air Quality in Texas: Summary of Scientific Projects and Findings from the Texas Air Quality Research Program 2010-2017. The University of Texas, Austin.

[43] TCEQ (2015) Information Submitted for the Limestone Generating Station and the WA Parish Electric Generating Station.

https://www.tceq.texas.gov/assets/public/implementation/air/sip/so2/2015RevisedR ecommendation/Att_F_NRG.pdf

[44] Friedfeld, S., Fraser, M., Ensor, K., Tribble, S., Rehle, D., Leleux, D. and Tittel, F. (2002) Statistical Analysis of Primary and Secondary Atmospheric Formaldehyde. Atmospheric Environment, 36, 4767-4775. https://doi.org/10.1016/S1352-2310(02)00558-7

[45] Seaman, N.L. (2000) Meteorological Modeling for Air-Quality Assessments. Atmospheric Environment, 34, 2231-2259. https://doi.org/10.1016/S1352-2310(99)00466-5

[46] Solomon, P., Cowling, E., Hidy, G. and Furiness, C. (2000) Comparison of Scientific Findings from Major Ozone Field Studies in North America and Europe. Atmospheric Environment, 34, 1885-1920. https://doi.org/10.1016/S1352-2310(99)00453-7

[47] Lei, W., Zhang, R., Tie, X. and Hess, P. (2004) Chemical Characterization of Ozone Formation in the Houston-Galveston Area: A Chemical Transport Model Study. Journal of Geophysical Research: Atmospheres, 109. https://doi.org/10.1029/2003JD004219

[48] Jeremiah Johnson, J.J., Kemball-Cook, S. and Yarwood, G. (2015) Photochemical Modeling of June 2006 for Hood County. Texas Commission on Environmental Quality.

[49] Kumar, A., Luo, J. and Bennett, G.F. (1993) Statistical Evaluation of Lower Flammability Distance (LFD) Using Four Hazardous Release Models. Process Safety Progress, 12, 1-11. https://doi.org/10.1002/prs.680120103 


\section{Appendix-A}

Comparison of modeled and observed concentrations: At the C696 station, the maximum observed hourly ozone concentrations of $109 \mathrm{ppb}$ occurred on 26th June, 14:00 hr, followed by $94 \mathrm{ppb}$ on 1st June, 16:00 hr. The corresponding CAMx modeled ozone was 99 ppb and 89 ppb respectively (Figure A-1). Bayland Park (C53) monitoring stations show a similar trend as C696, with observed maximums of $135 \mathrm{ppb}$ on $1^{\text {st }}$ June, $17: 00 \mathrm{hr}$ followed by $115 \mathrm{ppb}$ at $26^{\text {th }}$ June, 14:00 hr, the corresponding modeled ozone concentrations were $80 \mathrm{ppb}$ and 104 ppb respectively (Figure A-1). In the case of C556 station, the observed maximum

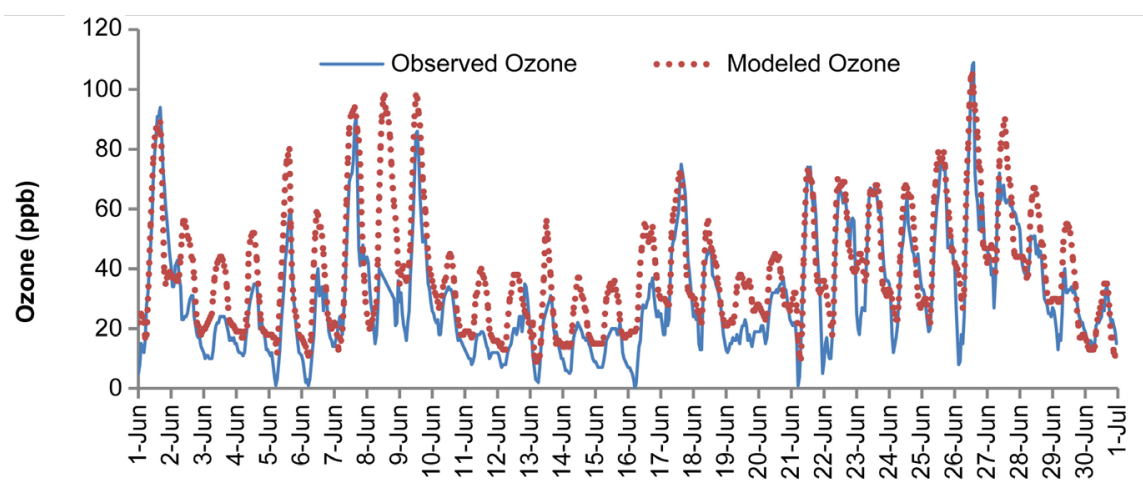

(a)

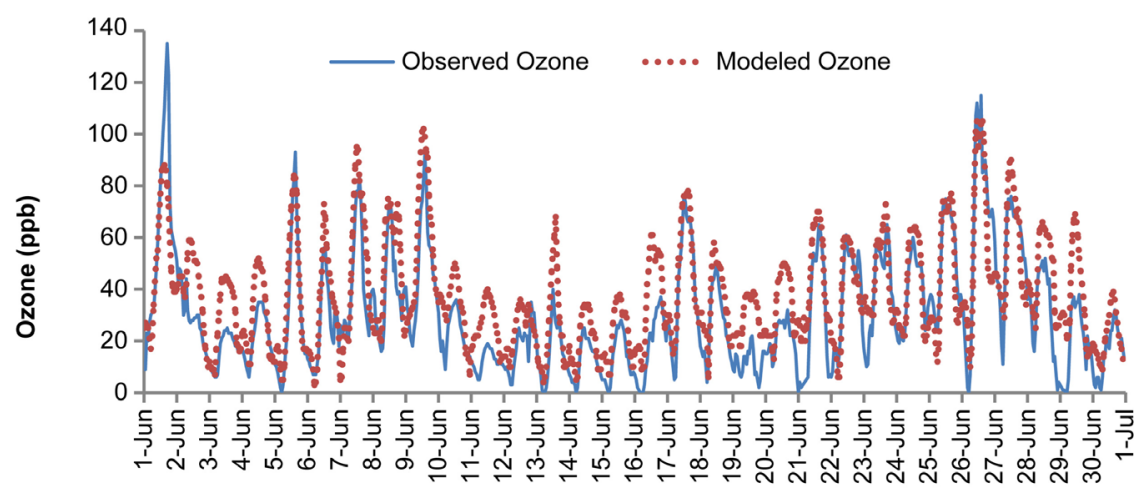

(b)

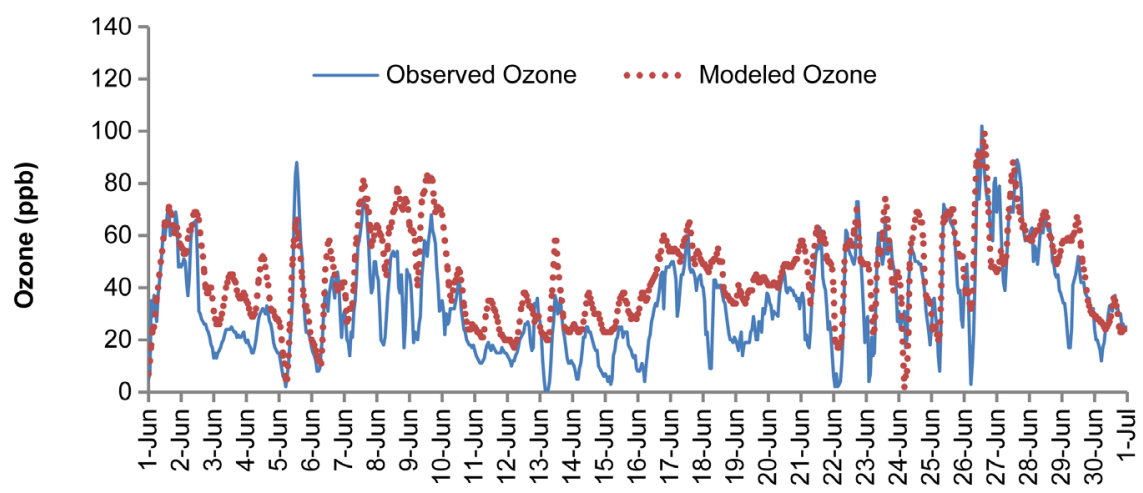

(c)

Figure A-1. Observed vs. modeled concentrations for comparison at (a) C696; (b) C53; (c) C556. 
of ozone was $102 \mathrm{ppb}$ on $26^{\text {th }}$ June, 13:00 $\mathrm{hr}$, while $87 \mathrm{ppb}$ in CAMx simulation (Figure A-1). The peak ozone occurs in afternoon for all three cases and simulated ozone consistently underestimates during high ozone episodes. Low ozone concentrations occur during midnight to morning. Meteorological inputs are the dominating factors for major uncertainty in photochemical modeling [45] [46]. Wind field, temperature, and cloud cover are the determining factors among the meteorological variables [47]. Cloud cover is not fully resolved by air quality models, which causes variation in predicted and observed ozone [42]. The surface boundary layer of the atmosphere is very shallow during night time, which is poorly described by meteorological models. Local sources of NOx emissions (e.g., nearby road) can exert a strong influence on ozone that is not replicated in a regional air quality model with $4 \mathrm{~km}$ square grid cells [48]. This study also applied statistical parameters to evaluate the performance of CAMx modeled vs. observed ozone concentrations. Two statistical parameters were used in this study: Fractional bias (FB) and coefficient of determination $\left(\mathrm{R}^{2}\right)$. If $\mathrm{FB}$ value ranges -0.5 to +0.5 , it can be inferred that the model performance is acceptable within $95 \%$ confidence interval [49]. $\mathrm{R}^{2}$ indicates the proportion of variation in measured ozone concentrations that can be explained by modeled ozone and evaluate how close the data fit the regression line. The ideal value of $R^{2}$ is 1 . Table $A-1$ shows the $F B$ and $R^{2}$ value for all three stations.

Table A-1. Observed vs. modeled concentrations for comparison at (a) C696; (b) C53; (c) C556.

\begin{tabular}{ccc}
\hline Site name & Fractional bias & $\mathrm{R}^{2}$ value \\
\hline C696 UH of Sugarland & 0.267 & 0.7844 \\
C53 Houston Bayland Park & 0.231 & 0.7465 \\
C556 La Porte Sylvan Beach & 0.273 & 0.6600 \\
\hline
\end{tabular}

